\title{
LATVIAN NONES AND CHRISTIANS: THEIR VALUE PROFILES
}

Mareks Niklass ${ }^{1}$, Dr.sc.soc./ researcher; Agita Misane ${ }^{2}$, Dr.phil./leading researcher ${ }^{1}$ University of Latvia; ${ }^{2}$ Riga Stradins University

\begin{abstract}
The present study explores the values of Christians as compared to those of the "religious nones" unchurched or religiously indifferent part of the Latvian society. The content of the term 'value' is often overlooked and the actual values of those who identify with religious tradition have remained insufficiently studied in Latvia. The authors use the theory of basic human values developed by Shalom H. Schwartz and the data from a representative survey carried out in 2015 to measure and compare the values of various religious groups. The logistic regression analysis identifies that one's religious affiliation have a significant impact on the higher order values of conservation and self-transcendence but No effect on one's openness to changes or self-enhancement. Borrowing from Scott Page's ideas on diversity, the authors conclude that various religious groups (including nones) within a religiously highly diverse society should inevitably become more similar by various measures including their value-orientations.
\end{abstract}

Key words: theory of basic human values, Christian values, religious nones. JEL code: N30.

\section{Introduction - the research problem and theoretical approach}

Already fifty years ago, social scientists had come up with as much as one hundred eighty different definitions of the term 'value' (Lautmann 1969) - we may assume that the number is even higher now. The authors of this paper have adopted the classical understanding suggested by Clyde Kluckhohn: „A value is a conception, explicit or implicit, distinctive of an individual or characteristic of a group, of the desirable which influences the selection from available modes, means, and ends of action" (Kluckhohn, 1951, p. 359). As Helmut Thome has acutely observed, this definition implies several distinctions (Thome, 2009, pp. 279-281). These are the distinctions of concepts, ideas or ideals versus valued or desired objects, the desired versus the desirable, and also the selection of modes and means of actions versus selection of perceptions. What is most important for the purpose of the present study - values serve as characteristics of certain identity, individual or collective. "Christian", "traditional" or "Latvian values" often evoked in the public discourse are all examples of the above. However, even the apologists of the above concepts often find it difficult to explain their contents.

In the public discourse of modern secular societies, the Christian message is sometimes deprived of its transcendent, ontological content and serves as a therapeutic culture-religion concerned mainly with preservation of the social order (Taylor, 2007). The authors believe it is the case also in Latvia and this is why collective value characteristics (like "Christian values" and "traditional values") are often used interchangeably. The content of the term 'value' is often overlooked and even more so, the actual values of those who identify with religious tradition have remained insufficiently studied.

This contribution is aimed at the exploration of values of the Christians as compared to the values of the "religious nones" - unchurched or religiously indifferent part of the Latvian society, i.e. individuals who would choose the option "none” when surveyed about their religious affiliation.

Empirical social research usually relies on the assumption that values are observable and measurable. The instrument presently used for such measurements is representative social surveys. Two most common modes of interpretation are those promoted by Ronald Inglehart's materialistic and post-materialistic value theory and Shalom H. Schwartz's theory of basic human values, respectively.

\footnotetext{
${ }^{1}$ Tel.: +371259971880 E-mail address: mareks.niklass@lu.Iv
} 
Inglehart's theory concentrates primarily on the value change as exemplified by the shift from materialistic to post-materialistic values (Inglehart, 1997). His understanding of value function reads as follows: "Value orientations set standards for desirable and undesirable goals" (Inglehart \& Wetzel, 2005, p. 23). Inglehart's two basic hypotheses are 'scarcity hypothesis', i.e. implying that individuals s objectively assign highest value to those entities that are limited in supply, and 'socialization hypothesis', stating that individuals' basic values are developed through lifetime and largely root in the socialization experience during their pre-adult life, i.e. "People tend to retain a given set of value priorities through adult life, once it has been established in their formative years."(Inglehart, 1997, p. 23).

Schwartz defines values as „desirable, trans-situational goals, varying in importance, that serve as guiding principles in the life of a person or other social entity" (Schwartz, 1994, p. 21). His theory identifies ten universal human values and organizes them in four groups. (Schwartz, 1994; Schwartz, 2003). These are further explained through sets of underlying motivators. The borders between the values are somewhat blurred as one may mix into another - theory also describes how the values are connected and affect each other, either in coordination or in contradiction. Thus, openness to change motivates self-direction and stimulation, self-enhancement drives hedonism, power and personal achievement, conservation is a motivator for security, conformity and tradition, while selftranscendence drives towards benevolence and universalism. Values can lightly or more strongly oppose each other, which has led Schwartz to the organization of the values in a circle along two polar dimensions or axes. The first dimension is openness to change versus conservation, or independence versus obedience. The second dimension is self-enhancement versus selftranscendence and opposes the interests of one-self and concern with the welfare of others.

The studies that compare Inglehart's and Schwartz's models remain few. Wilson (2005) has concluded that post-materialism is positively correlated with universalism, self-direction and benevolence (values of self-transcendence) but negatively correlated with conformity, security and power. Becker, Siegers and Kuntz (Becker, Siegers \& Kuntz, 2012, p. 20) have concluded that both theories have different theoretical and empirical contents and do not refer to the same underlying phenomena. They concluded that Scwartz's model is better suited to explain the social and moral attitudes of particular groups, similar conclusion has been reached in a study on political choices (Rossteutscher, 2005).

The aim of this study was to compare the values of the self-defined Christians in Latvia to those of 'nones' or religiously non-affiliated residents, using Shalom H.Schwartz'es basic human value theory. Thus we intend to discover if there are differences between the religious (Christian) and nonreligious segments of the Latvia's population and, also, between different Christian denominational and demographic groups.

\section{Data and methodology}

The present study analyses a data set of a representative survey of Latvian residents organized by the Advanced Social and Political Research Institute at the University of Latvia in 2015. The authors use the Schwartz's Human Values Scale (2003) to measure the value predispositions of Latvian residents. The questionnaire included 21 items asking respondents to agree or disagree with such statements like "Thinking up new ideas and being creative is important to him/her" or "Having a good time is important to him/her" (Schwartz, 2003, pp. 284-286). Respondents could choose answers from a six point Likert scale, where 1 correspondents to "very much like me", 2 - "like me", 3 - "somewhat like me”, 4 - „a little like me”, 5 - „not like me” and 6 - „not like me at all”. 
The authors derive four distinct higher order values from the Human Value Scale, i.e. openness to change, conservation, self-enhancement and self-transcendence. Openness to change indicates one's predisposition to pursue any intellectual or emotional directions one wishes, however unpredicTable or uncertain the outcomes (ESS EduNet, 2013). Conservation is about one's predisposition to preserve the status quo and the certainty in one's relationships with others. Selfenhancement is one's pursuit of self-interests even at the expense of others. At last, selftranscendence corresponds to one's predisposition to transcend one's interests and to promote the welfare of others (ESS EduNet, 2013).

The authors followed the same procedures how to construct new variables indicating each higher order value as indicated in the above European Social Survey website (ESS EduNet, 2013). The variables are the mean of those questionnaire items accounting for one or another higher order value. Therefore, they retain the same scale and are easy to interpret. Cronbach's alpha was calculated for each higher order value (see Table 1 ) to check the reliability of newly created items.

Table 1

\section{Cronbach's alpha for each of the higher-order values}

\begin{tabular}{|l|c|c|}
\hline \multicolumn{1}{|c|}{ Higher order values } & $\begin{array}{c}\text { Cronbach's } \\
\text { alpha }\end{array}$ & $\begin{array}{c}\text { Number of } \\
\text { questionnaire } \\
\text { items }\end{array}$ \\
\hline Openness to change & 0.689 & 6 \\
\hline Conservation & 0.627 & 6 \\
\hline Self-enhancement & 0.682 & 4 \\
\hline Self-transcendence & 0.654 & 5 \\
\hline
\end{tabular}

The Cronbach's alpha values are lower in comparison with other countries where similar studies have been conducted (Schwartz, 2003, p. 318). It suggests that the calculated higher order values and the subsequent study results should be carefully considered. However, it could be noted that Slovenia and Israel show similar results as regard to the Cronbach's alpha values, therefore, the current calculations are not to be viewed as something extraordinary (Schwartz, 2003, p.318).

Initially, the authors intended to use linear regression to find out which factors account for the value predispositions of Latvian residents. However, all items failed the test of normality and No transformation (log-transformation and square root calculations) redressed the issue. Another concern was multicollinearity between two important items included in regression models, i.e. one's religious affiliation and language spoken at home. In Latvia, those who identify themselves as Orthodox believers tend to be Russian speaking ( $81 \%$ in the sample). Similarly, Lutherans are predominantly ethnic Latvians (100 \% in the sample). At last, most items included in regression analysis are categorical variables (regions, religious affiliations, education level etc.). Hence, it would be difficult to establish linear relationship between dependent and independent variables.

As a result, the authors decided to dichotomize the scale with a cut point 2.5 on the Likert six point scale, which closely corresponds to the answers of respondents "very much like me" and "like me". The dichotomized higher order value items could be used in binary logistic regression analysis, which is a more robust method and less prone to the violations of different assumptions. The outcome (dependent) variable identifies two groups of respondents, i.e. those with distinct predisposition to a higher order value and those with low scores on the scale (with little or No predisposition). Logistic regression model shows which factors account for the predisposition of one's openness to changes or self-transcendence. 


\section{Empirical results}

The authors include nine dependent variables in logistic regression models. One's gender, age (three age groups), education level, employment status, minors at home, language spoken at home, religious affiliation, regions and an item indicating the attendance of regular church services in the last two years (see Table 2 for the descriptive statistics of the sample). Women and the elderly attend church services more often (Misane, 2014) and thus may have been exposed to church teachings more intensively. As indicated above, the language spoken at home and one's religious affiliation are closely correlated. There are also considerable regional differences in Latvia in terms of living standards, educational levels attained and urbanization. The presence of minors at home may influence one's lifestyle and outlook on many things. Caring parents may have to take into consideration the interests of others. The attendance of regular church services may promote certain value traits. Regular churchgoers may have more may be less likely to pursue their interests at the expense of others as this is what the church doctrine teaches.

Table 2

Description of Data Set for Logistic Regression Analysis

\begin{tabular}{|c|c|c|c|c|c|}
\hline \multirow{3}{*}{ Gender } & & $\%$ & & & $\%$ \\
\hline & Men & 46.2 & Regions & Riga & 31.3 \\
\hline & Women & 53.8 & & $\begin{array}{l}\text { Riga } \\
\text { metropolitan }\end{array}$ & 18.2 \\
\hline \multirow[t]{3}{*}{ Age } & $15-34$ & 33.7 & & Other regions & 50.5 \\
\hline & $35-54$ & 36.9 & Religious affiliation & Non-affiliated & 21.3 \\
\hline & $55+$ & 29.4 & & Orthodox & 30.1 \\
\hline \multirow[t]{4}{*}{$\begin{array}{l}\text { Educational } \\
\text { level }\end{array}$} & Primary & 16.4 & & Catholics & 21.2 \\
\hline & Secondary & 18.5 & & Lutherans & 21.2 \\
\hline & Secondary vocational & 31.3 & & Other Christian & 6.3 \\
\hline & Tertiary & 33.8 & $\begin{array}{l}\text { Regular service } \\
\text { attendance in the last } \\
\text { two years }\end{array}$ & Yes & 24.6 \\
\hline \multirow[t]{2}{*}{$\begin{array}{l}\text { Employment } \\
\text { status }\end{array}$} & $\begin{array}{l}\text { Not employed } \\
\text { (unemployed/inactive) }\end{array}$ & 37.6 & & No & 75.4 \\
\hline & Employed & 62.4 & $\begin{array}{l}\text { Dichotomized scores } \\
\text { for higher order values }\end{array}$ & $\begin{array}{l}\text { Openness to } \\
\text { change }\end{array}$ & 41.9 \\
\hline \multirow[t]{2}{*}{$\begin{array}{l}\text { Minors in one's } \\
\text { household }\end{array}$} & No minors & 71.8 & & Conservation & 48.2 \\
\hline & Minors & 28.2 & & $\begin{array}{l}\text { Self- } \\
\text { enhancement }\end{array}$ & 29.1 \\
\hline \multirow[t]{2}{*}{$\begin{array}{l}\text { Language } \\
\text { spoken at home }\end{array}$} & Non-Latvian & 38.8 & & $\begin{array}{l}\text { Self- } \\
\text { transcendence }\end{array}$ & 68.6 \\
\hline & Latvian & 61.2 & & & \\
\hline
\end{tabular}

*Atheists, non-Christians and those who could not identify their religious affiliation are not included. They represent $5.3 \%$ of all cases. Their numbers are too small to treat them as separate groups and analytic categories.

**"Dichotomized scores for higher order values" are calculated as a share of those respondents with values equal or less than 2.5 ( a cut point) on a six point scale where 1 stands for very much like me, 6 - not like me at all.

$41.9 \%$ of respondents may be identified as open to changes. One might expect that various factors account for that. However, the logistic regression model presented in Table 3 shows that only one's age and the presence of minors at home are the factors, which explain the value predisposition of openness to change. Young people aged 15-34 are much more likely to show the value trait. To a lesser degree, it holds true also for those who have children at home. One's education level and religious affiliation have No impact on one's openness to change. It is also sometimes believed that religious people are reluctant to embrace new ideas. $48.2 \%$ of respondents have scored high on the conservation scale. One might argue that a well-known pattern emerges. Women, older respondents, 
those living outside metropolitan areas, those affiliated with certain religious groups and church goers are more likely to score high on the conservation value scale. A closer inspection of the model shows some differences between religious groups. In comparison with "nones", Orthodox believers, Catholics and a small minority of other Christians groups tend be more predisposed to preserve the status quo. However, there are essentially No differences between non-affiliated and Lutherans in this regard. The interaction between one's language and religious affiliation also play a part. NonLatvian speaking population in different religious affiliation groups are more inclined to preserve the status quo.

Table 3

Predisposition of being open to changes and predisposition to conservation

\begin{tabular}{|c|c|c|c|c|c|}
\hline & & \multicolumn{2}{|c|}{$\begin{array}{l}\text { Open to } \\
\text { changes }\end{array}$} & \multicolumn{2}{|c|}{ Conservation } \\
\hline & & $\mathrm{p}$-value & $\operatorname{Exp}(b)$ & $\mathrm{p}$-value & $\operatorname{Exp}(b)$ \\
\hline \multirow[t]{2}{*}{ Gender } & Men (ref.) & & & & \\
\hline & women & 0.70 & 0.95 & 0.00 & 1.82 \\
\hline \multirow[t]{3}{*}{ Age } & $15-34$ & 0.00 & 5.43 & 0.00 & 0.33 \\
\hline & $35-54$ & 0.00 & 1.93 & 0.00 & 0.43 \\
\hline & $55+$ (ref.) & 0.00 & & 0.00 & \\
\hline \multirow[t]{4}{*}{ Education } & Primary & 0.62 & 1.13 & 0.06 & 0.64 \\
\hline & Secondary & 0.06 & 1.49 & 0.74 & 0.93 \\
\hline & Secondary vocational & 0.10 & 1.35 & 0.70 & 1.07 \\
\hline & Tertiary (ref.) & 0.21 & & 0.15 & \\
\hline \multirow[t]{3}{*}{ Employment status } & Not employed (ref.) & & & & \\
\hline & Employed & 0.41 & 1.15 & 0.60 & 0.92 \\
\hline & No minors (ref.) & & & & \\
\hline Minors in household & Minors & 0.00 & 1.84 & 0.56 & 1.10 \\
\hline \multirow[t]{2}{*}{ Language spoken at home } & Latvian & 0.52 & 1.30 & 0.32 & 1.56 \\
\hline & Non-Latvian (ref.) & & & & \\
\hline \multirow[t]{3}{*}{ Regions } & Riga (ref.) & 0.73 & & 0.03 & \\
\hline & Riga metropolitan & 0.43 & 1.19 & 0.75 & 0.93 \\
\hline & Other & 0.61 & 1.09 & 0.03 & 1.45 \\
\hline \multirow[t]{5}{*}{ Religious affiliation } & Non-affiliated (ref.) & 0.38 & & 0.05 & \\
\hline & Orthodox & 0.87 & 0.94 & 0.01 & 2.98 \\
\hline & Catholics & 0.17 & 0.51 & 0.04 & 2.77 \\
\hline & Lutherans & 0.54 & 0.87 & 0.25 & 1.30 \\
\hline & Other Christian & 0.41 & 0.65 & 0.01 & 4.64 \\
\hline \multirow[t]{4}{*}{$\begin{array}{l}\text { Interaction - religious affiliation } \\
\text { by language }\end{array}$} & $\begin{array}{l}\text { Religious } \\
\text { affiliation*language }\end{array}$ & 0.54 & & 0.08 & \\
\hline & $\begin{array}{l}\text { Other Christian by } \\
\text { Latvian }\end{array}$ & 0.87 & 0.88 & 0.05 & 0.21 \\
\hline & Orthodox by Latvian & 0.58 & 0.75 & 0.02 & 0.26 \\
\hline & Catholics by Latvian & 0.45 & 1.51 & 0.08 & 0.38 \\
\hline \multirow[t]{2}{*}{ Regular services attendance } & Yes & 0.38 & 1.16 & 0.02 & 1.46 \\
\hline & No (ref.) & & & & \\
\hline Constant & & 0.00 & 0.14 & 0.19 & 0.52 \\
\hline Hosmer \& Lemeshow & & 0.26 & & 0.18 & \\
\hline Nagelkerke R2 & & .149 & & .174 & \\
\hline Classification accuracy & & $66.7 \%$ & & $64.9 \%$ & \\
\hline
\end{tabular}


A minority of respondents (29.1\%) scored high on the self-enhancement scale. Logistic regression analysis (Table 4 ) reveals that young people and those living in Riga (a capital city with the highest living standard in Latvia) are more likely to pursue their self-interests. Other factors do not have any considerable effect on the value predisposition. Churchgoers are not different in this regard. About $2 / 3$ of respondents (68.6 \%) have high propensity scores on the self-transcendence scale. Self-transcendence is one's predisposition to look beyond one's self-interests and take care of other people. This value trait is more prevalent among women, older respondents, those living outside Riga, churchgoers and those affiliated with a certain religious group. Catholics, Orthodox believers, other Christians groups and, to a lesser degree, Lutherans tend to be more mindful of other people.

Table 4

\section{Predisposition to self-enhancement and self-transcendence}

\begin{tabular}{|c|c|c|c|c|c|}
\hline & & \multicolumn{2}{|c|}{$\begin{array}{c}\text { Self- } \\
\text { enhancement }\end{array}$} & \multicolumn{2}{|c|}{$\begin{array}{c}\text { Self- } \\
\text { transcendence }\end{array}$} \\
\hline & & $\mathrm{p}$-value & $\operatorname{Exp}(b)$ & $\mathrm{p}$-value & $\operatorname{Exp}(b)$ \\
\hline \multirow[t]{2}{*}{ Gender } & Men (ref.) & & & & \\
\hline & women & 0.26 & 0.84 & 0.00 & 1.56 \\
\hline \multirow[t]{3}{*}{ Age } & $15-34$ & 0.00 & 2.92 & 0.02 & 0.62 \\
\hline & $35-54$ & 0.02 & 1.65 & 0.03 & 0.63 \\
\hline & $55+$ (ref.) & 0.00 & & 0.05 & \\
\hline \multirow[t]{4}{*}{ Education } & Primary & 0.79 & 1.07 & 0.44 & 0.82 \\
\hline & Secondary & 0.79 & 1.06 & 0.81 & 0.95 \\
\hline & Secondary vocational & 0.77 & 0.95 & 0.49 & 0.88 \\
\hline & Tertiary (ref.) & 0.95 & & 0.85 & \\
\hline \multirow[t]{3}{*}{ Employment status } & Not employed (ref.) & & & & \\
\hline & Employed & 0.77 & 0.95 & 0.30 & 0.83 \\
\hline & No minors (ref.) & & & & \\
\hline Minors in household & Minors & 0.91 & 1.02 & 0.69 & 0.93 \\
\hline \multirow[t]{2}{*}{ Language spoken at home } & Latvian & 0.96 & 0.98 & 0.66 & 1.19 \\
\hline & Non-Latvian (ref.) & & & & \\
\hline \multirow[t]{3}{*}{ Regions } & Riga (ref.) & 0.00 & & 0.03 & \\
\hline & Riga metropolitan & 0.05 & 0.64 & 0.01 & 1.82 \\
\hline & Other & 0.00 & 0.52 & 0.04 & 1.44 \\
\hline \multirow[t]{5}{*}{ Religious affiliation } & Non-affiliated (ref.) & 0.97 & & 0.00 & \\
\hline & Orthodox & 0.86 & 1.07 & 0.01 & 2.70 \\
\hline & Catholics & 1.00 & 1.00 & 0.04 & 2.60 \\
\hline & Lutherans & 0.54 & 1.17 & 0.02 & 1.78 \\
\hline & Other Christian & 0.75 & 1.18 & 0.00 & 11.90 \\
\hline \multirow[t]{4}{*}{$\begin{array}{l}\text { Interaction - religious affiliation } \\
\text { by language }\end{array}$} & $\begin{array}{l}\text { Religious } \\
\text { affiliation*language }\end{array}$ & 0.27 & & 0.08 & \\
\hline & $\begin{array}{l}\text { Other Christian by } \\
\text { Latvian }\end{array}$ & 0.11 & 0.14 & 0.02 & 0.10 \\
\hline & Orthodox by Latvian & 0.67 & 1.26 & 0.11 & 0.44 \\
\hline & Catholics by Latvian & 0.53 & 1.42 & 0.10 & 0.42 \\
\hline \multirow[t]{2}{*}{ Regular services attendance } & Yes & 0.26 & 1.22 & 0.00 & 1.77 \\
\hline & No (ref.) & & & & \\
\hline Constant & & 0.02 & 0.32 & 0.78 & 1.14 \\
\hline Hosmer \& Lemeshow & & 0.69 & & 0.24 & \\
\hline Nagelkerke R2 & & .091 & & 0.131 & \\
\hline Classification accuracy & & $70.7 \%$ & & $69.8 \%$ & \\
\hline
\end{tabular}


A final technical note. The classification accuracy of the presented models is satisfactory. It ranges from $64.9 \%$ to $70.7 \%$. However, logistic regression models explain only a small share of the total variance ( $9 \%$ to $17 \%$ ). Most likely, other demographic and non-demographic have more impact on the value traits of respondents. Unfortunately, the questionnaire used in the study does not include more contextual items. This aspect should be taken into account when interpreting the results of the analysis presented in this paper.

\section{Discussion}

As regard to different factors that may account for one's value predispositions, two factors stand out, namely, respondent's age and place of residence (region). Young people living in Riga tend to be less conservative, less mindful of others and more likely to pursue their own interests. Older people and to a lesser degree women tend to be more conservative and more mindful of other people's interests. One's religious affiliation may have impact on the higher order values of conservation and self-transcendence. Orthodox believers, Catholics and a small minority of other Christians groups are more predisposed to preserve status que and more likely to transcend their own interests. Lutherans and nones differ very little - this supports earlier findings that of all Christian groups in Latvia, Lutheran's beliefs are most similar to the beliefs and worldview of the un-affiliated (Misane, 2014). At last, one's religious affiliation does not have a significant impact on one's openness to changes or pursuit of self-interests.

The minimal differences in value orientation between self-identified Lutherans, Roman Catholics and Russian Orthodox, and Latvian 'nones' is best explained by the structure and nature of religious diversity of the Latvian society. Latvia ranks high 5.7 on the PEW religious diversity index (2012) which places it above any other Baltic Sea nation. Moreover, had intra-religious diversity been considered in the calculation, the index would have been even higher as three largest denominations are represented by similar numbers of adherents. The number of nones is also very close. The same survey revealed that $20 \%$ of the Latvian population adhere to Lutheranism, 20,4 \% identify as Roman Catholics, $29 \%$ as Russian Orthodox, 20,4 \% do not belong to any religion and 3,3 \% are Atheists (Krumina-Konkova \& Misane, 2018, p. 742). Media often remark that the Christian churches in Latvia tend to grow more similar with time. This applies, in particular, to the growing closeness of the Evangelic Lutheran and Roman Catholic Churches and is evident both in the doctrinal developments and liturgical practices.

Scott Page describes three types of diversity, distinguishing diversity within a type or variation, diversity of types and kinds, and diversity of composition (Page, 2011, p. 20). Variation within a type plays important role in adaptability and robustness of given complex system and, hence, different actors in the field can occupy different niches and adapt to the environment. Different Christian denominations represent, in this respect, different variations of the same religion and thus attract, potentially, adherents with disparate religious goals and preferences. Difference of types, on the other hand, represent difference of functions and further, we suggest, disparate attitudes towards religion in general - this is how Christians and nones differ. The difference of composition refers to how the types are arranged. Examples of this would be religious groups with different legal status or position in the religious market and/or religious hierarchy. Marginal, less privileged religious communities that are subject to more regulation should, in theory, display more difference from the mainstream churches and the non-believers. 
In practice, this means that religious groups (including non-believers) within a religiously highly diverse society should inevitably become more similar by various measures, including valueorientation, due to their interdependence within their shared religious environment and history while providing for the religious needs of the population.

\section{Conclusions}

1) The present study explores the values of Christians as compared to those of the "religious nones" - unchurched or religiously indifferent part of the Latvian society. "Christian", "traditional" or "Latvian values" are often used interchangeably. The content of the term 'value' is often overlooked or poorly defined and the actual values of those who identify with religious tradition have remained insufficiently studied in Latvia.

2) The authors use the theory of basic human values developed by Shalom $\mathrm{H}$. Schwartz and the data from a representative survey carried out in 2015 to measure and compare the values of various religious groups. By using logistic regression analysis, the authors seek to identify various factors that may account for one's value traits as well as to find out value differences between various religious affiliation groups.

3) The logistic regression analysis reveals that young people living in Riga tend to be less conservative, less mindful of others and more likely to pursue their own interests. Older people and to a lesser degree women tend to be more conservative and more mindful of other people's interests.

4) The analysis also identifies that one's religious affiliation have a significant impact on the higher order values of conservation and self-transcendence but No effect on one's openness to changes or self-enhancement. Orthodox believers, Catholics and a small minority of other Christians groups are more predisposed to preserve status que and more likely to transcend their own interests. Lutherans and nones differ very little thus conforming earlier findings in other studies in Latvia.

5) Borrowing from Scott Page's ideas on diversity, the authors conclude that various religious groups (including nones) within a religiously highly diverse society should inevitably become more similar by various measures including their value-orientations.

\section{Bibliography}

1. Becker, T., Siegers, P., and Kuntz, A. (2012). Congruence and Performance of Value Concepts in Social Research. Survey Research Methods, Vol.6, No.1, pp. 13-24.

2. ESS EduNet. (2013). Chapter 5: Higher-order Values. Retrieved: http://essedunet.nsd.uib.no/cms/topics/1/5/all.html

3. Inglehart, R.( 1997). Modernization and Post-modernization: Cultural, Economic, and Political Change in 43 Societies. Princeton: Princeton University Press.

4. Kluckhohn, C.K.M. (1951). Values and Value Orientations in Theory of Action. In: Parsons, T. \& Shils, E. Toward a General Theory of Action. Cambridge, MA: Harvard University Press, pp. 188-433.

5. Krumina-Konkova, S. \& Misane, A. (2018). Religions in Latvia. In: Latvia and Latvians. Riga: Latvian Academy of Sciences. pp. 720-751.

6. Lautmann, R. (1969). Wert und Norm. Begriffsanalysen für die Soziologie. Cologne \& Opladen: Westdeutscher Verlag.

7. Misane, A. (2014). Latvijas iedzivotaju religiskas identitates un religiozitates dinamika pec neatkaribas atjaunosanas.In: Rozenvalds, J. \& Zobena, A. (eds.) Daudzveidegas un mainigas Latvijas identitates. Riga: LU Akademiskais apgads. 284-295.Ipp.

8. Page, S. (2011). Diversity and Complexity. Princeton \& Oxford: Princeton University Press.

9. Rossteutscher, S. (2004). Explaining Politics: an Empirical Test of Competing Value Measures. European Journal of Political Research, 43, pp.769-799.

10.Schwartz, S.H. (1994). Are There Universal Aspects in the Structure and Contents of Human Values? Journal of Social Issues, Vol. 50, pp.19-45. 
11.Schwartz, S. H. (2003). A Proposal for Measuring Value Orientations across Nations. Chapter 7 in the Questionnaire Development Package of the European Social Survey. Retrieved:

http://www.europeansocialsurvey.org/docs/methodology/core_ess_questionnaire/ESS_core_questionnaire_ human_values.pdf

12. Taylor, C. (2007). A Secular Age. Cambridge, MA: Harvard University Press.

13. Thome, H. ( 2009). Value Change in Europe from the Perspective of Empirical Social Research. In: The Cultural Values of Europe. Eds. H.Joas \& K. Wiegandt. Liverpool: Liverpool University Press.

14. Wilson, M.S. (2005). The Social Value-Analyses of Postmaterialism. The Journal of Social Psychology, 145, pp. 209-224. 